\section{Immunoexpression of PPAR $-\gamma$ and Osteocalcin Proteins for Bone Repair of Critical-Size Defects Treated with Fragmented Autogenous Abdominal Adipose Tissue Graft}

Tatiana Miranda Deliberador, Allan Fernando Giovanini, Tertuliano Ricardo Lopes, João César Zielak, Alexandre Moro, Flares Baratto Filho, Felipe Rychuv Santos, Carmen L. Mueller Storrer
'Graduate Program in Dentistry, UP Positivo University, Curitiba, PR, Brazil

Correspondence: Profa. Dra. Tatiana Miranda Deliberador, Rua Professor Pedro Viriato Parigot de Souza, 5300, Campo Comprido, 81280-3300 Curitiba, PR, Brasil. Tel: +55-41-33173000. email: tdeliberador@gmail.com
Immunoexpression of PPAR- $\gamma$ and osteocalcin proteins was evaluated for bone repair of critical-size defects (CSDs), created in rat calvaria $(n=42)$ and treated with fragmented abdominal autogenous adipose tissue graft. Three groups $(n=14)$ were formed: $C$ (control - blood clot), AB (autogenous bone) and AT (fragmented adipose tissue). The groups were divided into subgroups $(n=7)$ for euthanasia at 30 and 90 days. Histological and immunohistochemical analyses were performed. Data were subjected to descriptive statistics (mode). A complete bone closure was observed in Group AB 90 days after surgery. In Group C, repair was achieved by the formation of collagen fiber bundles oriented parallel to the wound surface at both post-surgery periods. In Group AT the type of healing was characterized by dense connective tissue containing collagen fiber bundles arranged amidst the remaining adipose tissue, with rare heterotopic bone formation associated with fibrosis and different types of tissue necrosis. Immunostaining of PPAR- $\gamma$ was not observed in any specimen from Groups $C$ and AB. In Group AT, the immunostaining of PPAR- $\gamma$ was more evident 30 days after surgery. Immunostaining of osteocalcin was present in all groups and at both postoperative periods. The fragmented autogenous abdominal adipose tissue graft did not favor the repair of critical-size bone defects created surgically in rat calvaria as evidenced by the positive immunostaining of PPAR- $\gamma$ protein and the negative immunostaining of osteocalcin in the osteoblast-like cells and bone matrix.
Key Words: adipose tissue, skull, bone transplantation, bone regeneration, immunohistochemistry.

\section{Introduction}

Bone tissue has a high self-repair capacity. However, repair may not be complete in extensive bone defects due to invasion of surrounding connective tissues, whose cell proliferation and migration are faster than those of bone tissue. Thus, use of bone grafts, biomaterials, stem cells and growth factors may collaborate in the repair process (1).

The search for new materials or methods that assist the process of bone and tissue repair has been following different paths from those characterized by the use of autogenous, allogeneic (homogenous), xenogeneic (heterogeneous) bone, and alloplastic materials. The use of stem cells is presented as one of these paths (2).

Stem cells are undifferentiated and have the capacity for self-renewal and differentiation into other cells of the body. There are two categories of stem cells: embryonic (pluripotent) and adult (unipotent or multipotent) ones (3).

Stem cells derived from adipose tissue are potentially ideal as a source of cells, not only because adipose tissue is relatively abundant, but also because its collection (liposuction) is a much less invasive procedure when compared to the collection of bone marrow cells $(4,5)$. Furthermore, the stromal vascular fraction of the adipose tissue contains up to $2 \%$ of stem cells with the potential for differentiation into osteoblasts, chondrocytes, adipocytes, and neurons, in comparison to $0.002 \%$ stem cells derived from the mesenchymal bone marrow (6).

In vitro and in vivo studies (7-11) demonstrated that stem cells derived from adipose tissue are a promising source to aid in the repair of bone tissue. Cowan et al. (7) demonstrated that stem cells from adipose tissue along with a structure of apatite polylactic glycolic acid have osteoconductive capacity and can repair a critical-size defect (CSD) in a rat's skull. This explains why mature adipocytes have the capacity for transdifferentiation into osteoblasts, both in vitro and in vivo, which makes adipocytes good candidates for tissue engineering protocols that aim the development of bone tissue (12).

Despite all advances in the use of stem cells derived from adipose tissue for the repair of bone defects, there 
are few studies in the literature that used autogenous adipose tissue as a grafting material for the treatment of maxillary $(13,14)$ and cranial bone defects $(15)$. Matsubara et al. (14) also observed that the use of adipose tissue graft did not favor the repair of dehiscence bone defects created surgically in dental implants placed in rabbit tibiae.

On the other hand, bone repair has been effectively achieved when fragmented autogenous adipose tissue graft was used to treat cranial bone defects. Gomes et al. (15) evaluated, by histological and immunohistochemical analyses, the use of fragmented (macerated) autogenous white adipose tissue graft, originally subcutaneous, for bone repair of CSDs created surgically in rabbit calvaria. The authors concluded that this type of graft is a promising material to achieve bone repair, since a prominent immunoexpression of the BMP-2 and CD-34 bone proteins has been demonstrated, which indicates that the adipocytes transdifferentiated into osteoblasts.

The evaluation of the osteoblast differentiation is commonly done by means of different biochemical markers of bone metabolism (bone proteins), which can be identified by immunohistochemistry. Two markers of bone formation were used in this research: osteocalcin and Peroxisome proliferator activated receptor gamma (PPAR gamma or PPAR- $\gamma$ ).

Osteocalcin is a peptide secreted by mature osteoblasts, hypertrophied chondrocytes and odontoblasts. The emergence and growth of this protein are coincident with the beginning of the mineralization process (16) and osteogenesis (17).

PPAR- $\gamma$ is a nuclear receptor that functions as a master transcriptional regulator of the adipocyte conversion. PPAR- $\gamma$ intensifies the gene expression of adipogenesis (18). During the trans-activation of PPAR- $\gamma$ multiple signaling pathways can interact with each other, leading to differentiation of the white and/or brown adipose tissues (19). PPAR- $\gamma$ may act as a molecular switch during the osteogenic and adipogenic differentiation (18).

The objective of this paper was to evaluate the immunoexpression of the PPAR- $\gamma$ and osteocalcin proteins for bone repair of CSDs created surgically in rat calvaria and treated with fragmented abdominal autogenous adipose tissue graft.

\section{Material and Methods}

The research protocol was approved by the local Ethics Committee under the protocol \#019/2009.

Forty-two male rats (Rattus norvegicus albinus, Wistar), aged 5 to 6 months and weighing 400 to $600 \mathrm{~g}$ were used. The animals were randomly divided into three groups: Group $C$ (control), Group AB (autogenous bone), and Group AT (fragmented adipose tissue), and then subdivided into two groups for euthanasia at 30 and 90 days after surgery $(n=7)$. The animals were healthy and were kept in cages containing 4 animals each. They were given solid food and mineral water ad libitum at Positivo University animal care facility.

For the experimental surgical procedures, the animals were individually positioned inside a bell jar and were anesthetized with inhalation of isoflurane and oxygen followed by an intramuscular injection in the posterior thigh of with $2.3 \mathrm{~g}$ xylazine $(0.52 \mathrm{mg} / \mathrm{kg})$ and ketamine $1.16 \mathrm{~g}(1.04$ $\mathrm{mg} / \mathrm{kg}$ ). After anesthesia, the rats were positioned on an operating table while anesthesia was maintained with the vaporization of isoflurane by a facial mask when required.

After induction of anesthesia, the recipient sites were shaved and a depilatory cream was spread on their skulls as well as on the abdominal region in the animals of Group AT. The calvarial surgery to obtain a transosseous CSD was performed as described by Gomes et al. (15). The autogenous bone was taken from a portion of the skull cap, which was also removed to create the surgical defect. The bone was crushed with the help of mortar and pestle. An incision measuring approximately $1 \mathrm{~cm}$ was performed with a \#15 blade, parallel to the right hind limb in the abdominal region, in order to obtain autogenous adipose tissue. The adipose tissue from the exposed region was removed carefully with scissors and tweezers, macerated with a \# 15 scalpel blade by making random cuts in different directions, and immediately placed on the surgical defect. The soft tissues were repositioned and sutured with a 4-0 silk suture thread for a primary closure of the wound, both in the donor (abdominal region) and in the recipient site (calvaria). In Group C (negative control), the surgical defect was filled only with a blood clot. In Group AB (positive control), the defect was filled with crushed autogenous bone graft. In Group AT, the defect was filled with the fragmented autogenous adipose tissue graft removed from the abdominal region.

To control postoperative pain, the animals received an intramuscular injection of morphine sulfate $(3 \mathrm{mg} / \mathrm{kg}$ ) at the end of the surgery. Analgesia was maintained by dissolving 20 drops of acetaminophen $(200 \mathrm{mg} / \mathrm{kg})$ in 400 $\mathrm{mL}$ of water inside the bottle for 3 days.

The groups were divided into 2 subgroups $(n=7)$ for euthanasia at 30 and 90 days after surgery. The international and local rules for animal welfare were fully respected. The rats were placed in a $\mathrm{CO}_{2}$ gas chamber and kept there for $10 \mathrm{~min}$, which is the time needed for euthanasia to be completed.

The original surgical defect area and its surrounding tissues were removed in blocks. The specimens were fixed in $10 \%$ neutral formalin, washed in tap water, and decalcified in $20 \%$ formic acid. After decalcification, each specimen was bisected through its core, parallel to the sagittal 
suture and the long axis. The specimens were processed and embedded in paraffin. Longitudinal $3-\mu m$-thick serial sections were performed starting from the core of the original surgical defect.

\section{Histological Analysis}

Two histological sections were selected from each animal, representing the core of the original surgical defect, for histological and immunohistochemical analyses, performed by a single, previously trained operator.

For histological analysis, the images were captured by light microscopy and the following parameters were assessed: closure of the bone defect, type of the newly formed bone, characteristics of the connective tissue, presence of osteoid matrix, presence of acute or chronic inflammatory infiltrate, progression of the repair type in the surgically created defect, and thickness of the newly formed tissue in relation to the original bone of the skull cap. Closure of the defect was considered complete when all its extent was filled with newly formed bone. In addition, presence of remaining fragmented adipose tissue graft was also evaluated.

To evaluate data from the histological analysis, a method of semi-quantitative score was used, with scores ranging from: "-" for absence of markings up to 10\% of immunopositivity; "+" for 10 to $25 \%$; "++" for 25 to $50 \%$; "+++" for 50 to 75\%; and "++++" for more than 75\%.

\section{Immunohistochemical Analysis}

Immunohistochemical antiperoxidase was performed with the antibody anti-PPAR- $\gamma$ and osteocalcin. Immunoexpression of the protein was obtained by the method of streptavidin-biotin immunoperoxidase.

The images of each field were obtained by light microscopy at $\times 400$ magnification through bright-field fixed focus. Then, the images displayed on a TV monitor connected to a computerized system were scanned by a camera system attached to a light microscope. After that, manual counting of the nuclei that expressed immunostaining of the proteins PPAR- $\gamma$ and osteocalcin was performed.

Counting of the immunopositive cells for the PPAR- $\gamma$ and osteocalcin antibody was performed twice in every surgical defect by a single observer.

To evaluate data from the immunohistochemical analysis, a method of semi-quantitative score was used, with scores ranging from: "-" for absence of markings up to $10 \%$ of immunopositivity; "+" for 10 to $25 \%$; "++" for 25 to $50 \%$; "+++" for 50 to $75 \%$; and "++++" for more than $75 \%$. A semi-quantitative immunohistochemical analysis was performed because the PPAR- $\gamma$ and osteocalcin proteins were expressed both in cells and in the extracellular matrix.

\section{Statistical Analysis}

Descriptive statistics was performed using mode. Mode is the value with the largest number of observations, that is, the most frequent of all values. Unlike the mean or the median, the mode is not necessarily expressed in a single result. It is especially useful when the value or observations are not numerically expressed, or when the mean and median are not well defined.

\section{Results}

\section{Qualitative Histological Analysis}

Group C (control). At 30 and 90 days after surgery, a complete bone closure of the defect was not achieved in any of the specimens considering both postoperative periods. Presence of chronic inflammatory infiltrate was detected. The surgically created bone defect was filled with collagen fibers arranged parallel to the wound surface and a small amount of newly formed bone tissue could be observed on the margins of the defect, along with the remaining bone.

Group AB (autogenous bone). At 30 days after surgery, complete bone closure of the surgical defect was not achieved in this postoperative period. Most of the defect was filled with granulation tissue richly cellularized with areas of compact bone neoformation, which mimicked the formation of a Haversian bone. Giant cells were not detected in any specimen. At 90 days postoperatively, complete bone closure of the surgical defect was achieved in 6 out of the 7 specimens analyzed in this period. The entire extent of the defect was filled with Haversian compact bone tissue in which an area of discrete medullary maturation was observed.

Group AT (adipose tissue). At 30 and 90 days after surgery, there was no complete bone closure of the defect. Reparative histological analysis showed the presence of dense connective tissue with bundles of collagen fibers amidst the remaining adipose tissue (Fig. 1A) and 90 days after surgery, presence of heterotopic bone formation associated with fibrosis was detected (Fig. 1B). The fibers had a pale color that characterizes formation of osteoid structure, in which isolated fragments of mature newly formed bone tissue were found. Newly formed bone tissue was evident on the defect margins and the tissue thickness was similar to the original bone volume of the skullcap.

\section{Quantitative Histological Analysis}

Results of the quantitative histological analysis are shown in Table 1. The type of prevalent necrosis was not depicted in the score quantitative analysis. All groups showed presence of microcystic and ischemic necrosis, especially the group in which the defect was filled with adipose tissue. The groups filled with adipose tissue associated with particulate autogenous bone showed a 
prevalence of liquefactive-like inflammatory necrosis.

\section{Quantitative Immunohistochemical Analysis}

The results of quantitative immunohistochemical analysis are shown in Table 2.

\section{Qualitative Immunohistochemical Analysis PPAR- $\gamma$}

Immunostaining of the PPAR- $\gamma$ protein was not observed in groups $C$ and $A B$ in the periods of 30 and 90 days after surgery (Fig. $2 \mathrm{~A}-\mathrm{D}$ ). This was coincident with a discrete or absent marrow-adipose formation in the defects that had adipose autogenous material inserted.

In contrast, in group AT, the PPAR- $\gamma$ was identified in isolated cells of the adipose tissue grafted in the defects 30 days after surgery (Fig. 2E). However, the immunostaining of PPAR- $\gamma$ was either very low or occasionally absent (Fig. 2F) 90 days after surgery. These results indicate little activity of fat metabolism and possibly a loss of metabolic activity while a necrotic tissue is apparent.

\section{Osteocalcin}

Osteocalcin was detected in all specimens from all groups. In group $C$, the prevalence of a positive osteocalcin area coincided with the borders of the surgical defect along with the remaining bone. This result was similar in both postoperative periods, 30 and 90 days after surgery (Fig. 3A,B).

In group $A B$, a large amount of osteocalcin-positive cells was detected, not only surrounding the particulate bone tissue grafted inside the surgically created defect, but also in the defect itself. The quantification of osteocalcin was lower 90 days after surgery, which coincided with a lower area of repair and an incomplete closure of the defect (Figs. 3C,D).

In group $\mathrm{AT}$, osteocalcin also days after surgery in all groups

\begin{tabular}{lcccc}
\hline Protein & Postoperative period & Control & Autogenous bone & Adipose tissue \\
\hline PPAR- $\gamma$ & 30 days & - & - & +++ \\
& 90 days & - & - & + \\
Osteocalcin & 30 days & ++ & +++ & + \\
& 90 days & + & ++ & + \\
\hline
\end{tabular}
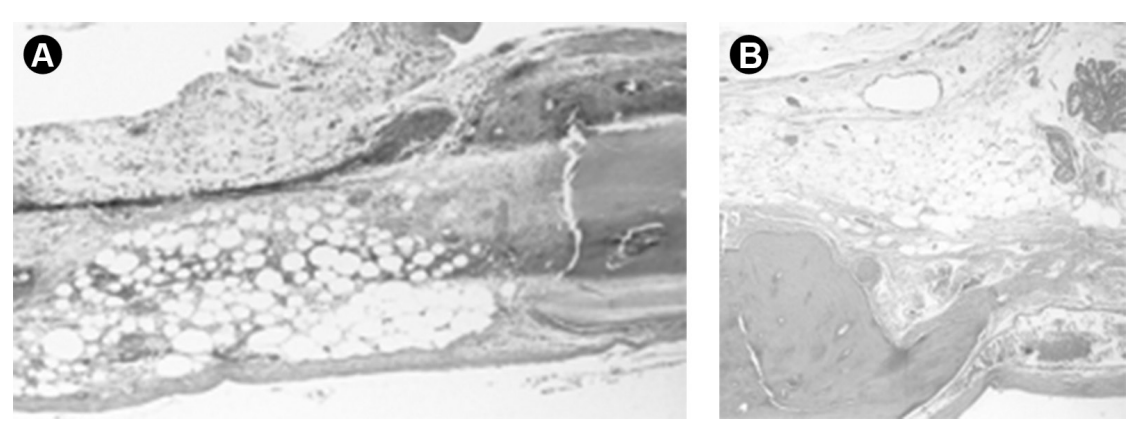

Figure 1. Group AT at 30 days (A) and 90 days (B). Defect filled with connective tissue arranged in collagen fibers amidst the remaining adipose tissue. Figure B shows adipose tissue with heterotopic bone formation. $\mathrm{HE}$, original magnification 40x. occurred in both postoperative periods, 30 and 90 days after surgery (Figs. 3E,F). However, neither osteoblast-like cells nor the bone matrix showed immunopositivity. In this group, the positive osteocalcin areas were diffusely arranged throughout the defect between the areas of necrosis, which possibly indicates a necrotic mineralization.

\section{Discussion}

There is a constant search to find a grafting material similar to the autogenous bone in its characteristics and results, considered the gold standard to achieve satisfactory bone repair in different types of bone defects. The use of stem cells from adipose tissue has been considered one of 
the most recent successful alternatives for the treatment of hard (7) and soft tissue defects (2). However, there are only few studies evaluating the use of cells derived from autogenous adipose tissue graft to achieve bone repair. Therefore, the aim of this study was to evaluate histologically and immunohistochemically, the bone repair of critical-size surgically created defects in rat calvaria and treated with fragmented abdominal autogenous adipose tissue graft.

In this research, the calvaria of rats was chosen due to its several similarities to the maxillofacial region as well as to its low regenerative capacity $(21,22)$. Therefore, CSD with $5 \mathrm{~mm}$ diameter was produced surgically. A CSD is defined as the smallest intraosseous wound in a particular bone of animal species, which is not supposed to heal spontaneously in the animal's lifetime (20). In group C, the results showed a limited bone neoformation not reaching the full bone closure of surgical defect in any specimen in both postoperative periods. Most part of the surgical defect was filled with connective tissue. This confirms the critical nature of this group and its limited regenerative capacity, which allowed a real assessment of the use of autogenous adipose tissue graft and its impact on bone repair.

Recently, Gomes et al. (15) demonstrated that the fragmented (macerated) autogenous adipose tissue graft has a significant potential for craniofacial bone repair in a study done in rabbit calvaria. The authors reported that the adipose tissue graft resulted in bone repair by the transdifferentiation of adipocytes into osteoblasts. In the present research, fragmented autogenous adipose tissue graft was also used in CSD to achieve bone repair in group AT. However, the results were not as expressive and meaningful as the results presented by Gomes et al. (15). In Group AT, the repair was predominantly characterized by dense connective tissue and 90 days after the procedure heterotopic bone formations were detected. One hypothesis concerning this different result may be the animal model and the region from which the adipose tissue was removed. In this study, the adipose tissue was removed from the abdominal region of rats while in another study (15) the
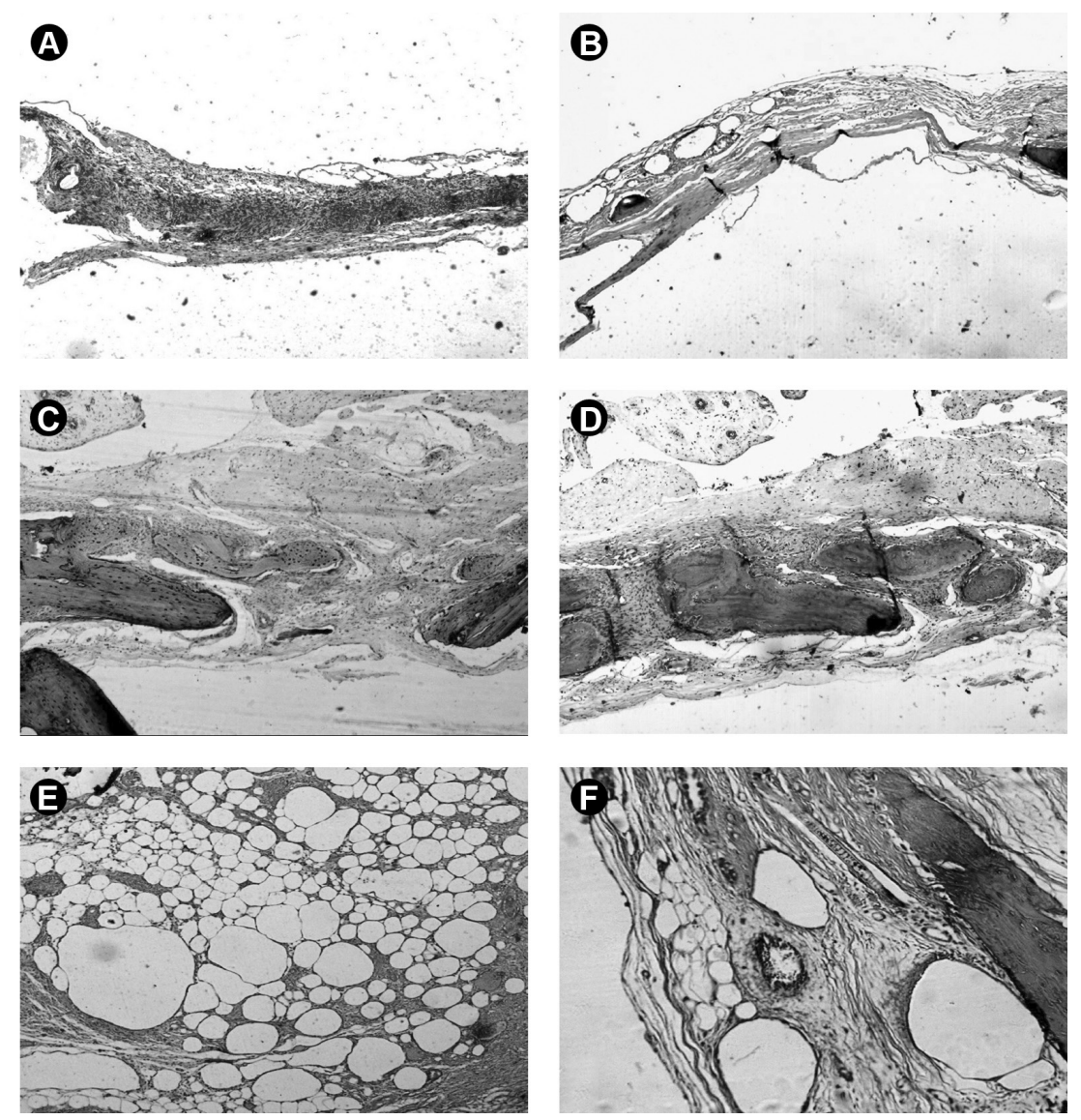

Figure 2. Immunostaining of the PPAR- $\gamma$ protein among all groups. A and B show the absence of immunostaining of the PPAR- $\gamma$ protein in the Control group 30 and 90 days after surgery, respectively (original magnification $\times 40$ ). C and D show the absence of immunostaining of the PPAR- $\gamma$ protein in group Autogenous bone at 30 and 90 days after surgery, respectively (original magnification $\times 100$ ). E shows positive immunostaining of the PPAR- $\gamma$ protein in group Adipose Tissue at 30 days after surgery (original magnification $\times 200$ ). F shows positive immunostaining of a small amount of the PPAR- $\gamma$ protein in group Adipose Tissue 90 days after surgery (original magnification $\times 40$ ). 
graft was removed from the dorsal region (back) of rabbits. Although both recipient areas have subcutaneous white adipose tissue, which has beneficial effects on bone and systemic metabolism for containing connective stromal adipocytes, nervous tissue, stromal vascular cells, lymph nodules, leukocytes, macrophages, fibroblasts and stem cells (6), the differences between both studies are evident.

In addition to the subcutaneous white adipose tissue, there is the visceral white adipose tissue which has a different metabolic effect in comparison with the subcutaneous tissue. The visceral adipose tissue is directly responsible for obesity and is associated with pathological conditions. Differences between these types of adipose tissue may be important for transplantation, and the subcutaneous adipose tissue, when compared with the visceral tissue, is considered beneficial because of its metabolism and also for being rich in CD34+ cells (15). In group AT, a great deal of remaining adipose tissue was detected in both postoperative periods. Based on these findings, a mistake may have occurred in relation to the donor site from which the adipose tissue was collected. In fact, visceral adipose tissue may have been collected and grafted rather than the subcutaneous adipose tissue. One of the limitations faced during this research was the difficulty to differentiate the kind of adipose tissue collected from the donor site. This is justified since the visceral tissue (related to obesity) is less absorbed and does not have the same metabolism and capacity for transdifferentiation in comparison to the subcutaneous tissue (6). This became evident because the immunostaining of the PPAR- $\gamma$ protein was identified in isolated cells of the grafted adipose tissue 30 and 90 days after surgery.

The immunostaining of the PPAR- $\gamma$ was very low and sometimes absent. Such a result indicates little activity of fat metabolism. Moreover, the presence of positive immunostaining of the PPAR- $\gamma$ in the early stages of healing indicates that the process of osteogenesis was impaired (18). This process was observed in this study because a satisfactory bone neoformation to repair the CSD was not achieved. Furthermore, the visceral adipose tissue is poor in CD34+ cells, thus the healing process occurred without a proper angiogenesis, which might result in lack of repair
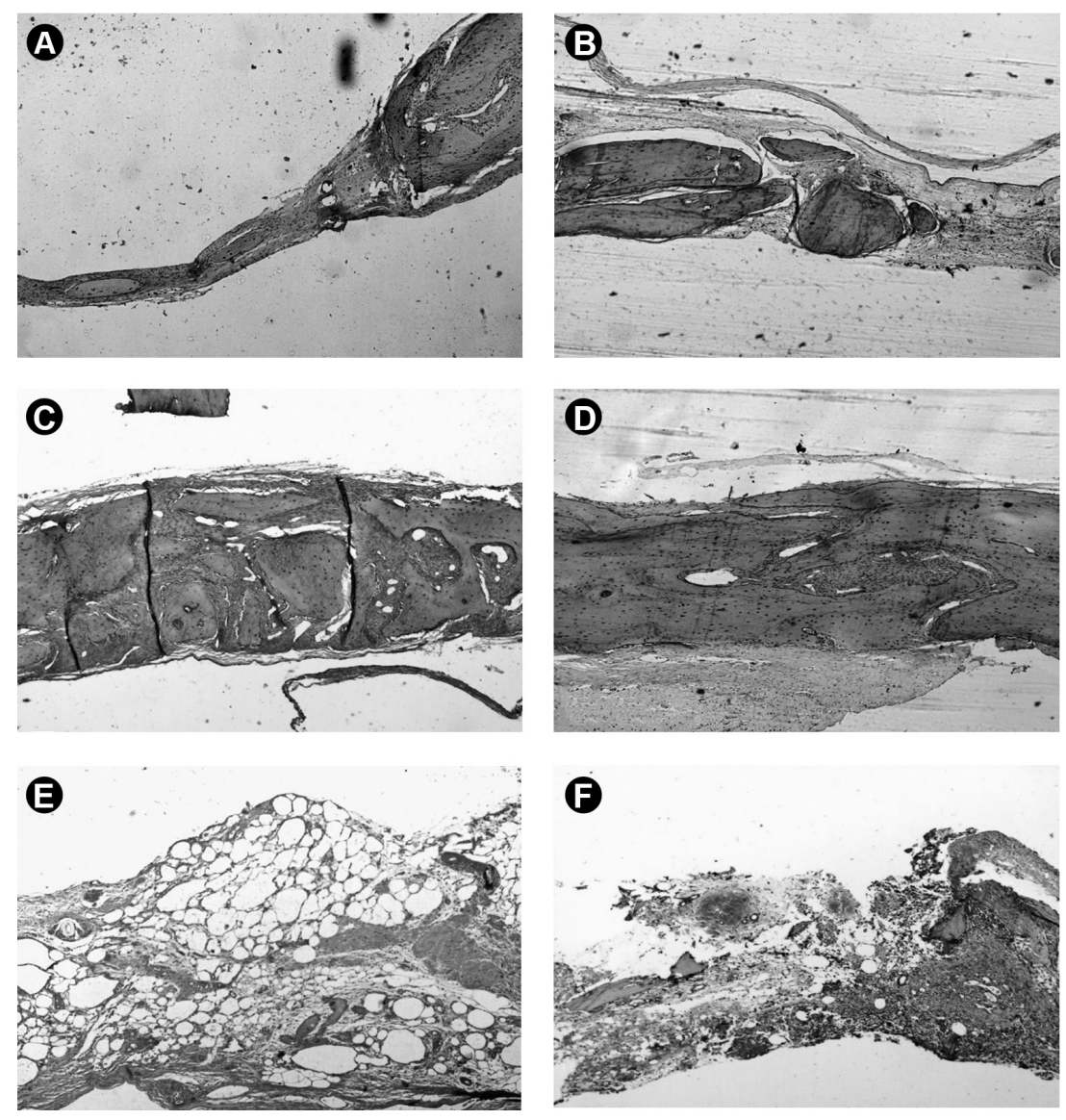

Figure 3. Immunostaining of the osteocalcin protein among all groups. A and B show positive immunostaining of the osteocalcin protein in the Control group 30 and 90 days after surgery, respectively. C and D show positive immunostaining of the osteocalcin protein in Group Autogenous bone at 30 and 90 days after surgery respectively, but more intensely at 30 days after surgery. E and F show positive immunostaining of the osteocalcin protein in group Adipose Tissue at 30 and 90 days after surgery, respectively. Original magnification 40x. 
due to a process of tissue necrosis. This was observed in Group AT whose remaining adipose tissue was associated with microcystic or ischemic necrosis, which reduced the labeling of the PPAR- $\gamma$ protein 90 days after surgery.

In Group AB specimens, presence of bone neoformation and a large amount of osteocalcin positive cells (Chart 2) was detected, encircling the particulate bone tissue grafted into the surgically created defect as well as inside the defect. These results confirm the hypothesis that the autogenous bone graft is really the gold standard of grafting materials for being osteogenic, osteoinductive and osteoconductive. Presence of osteocalcin was also detected in Group AT. However, positive osteocalcin areas were arranged diffusely throughout the defect between the areas of necrosis, which possibly indicates a necrotic mineralization that was mimicking a pathological calcification and creating a false impression of bone neoformation. In this sense, the fragmented abdominal autogenous adipose tissue did not promote transdifferentiation of adipocytes into osteoblast in the rat animal model.

According to the methodology used in this study and the obtained results, the fragmented autogenous abdominal adipose tissue graft did not favor the repair of critical-size bone defects created surgically in rat calvaria, as evidenced by the positive immunostaining of the PPAR-g protein and the negative immunostaining of osteocalcin in the osteoblast-like cells and bone matrix. Future studies in vivo are required in order to investigate the possibility to graft this type of adipose tissue.

\section{Resumo}

A imunoexpressão das proteinas PPAR- $\gamma$ e osteocalcina foi avaliada para o reparo ósseo de defeitos de tamanho critico (DTC) criados em calvária de ratos $(n=42)$ e tratados com enxerto de tecido adiposo autógeno abdominal macerado. Foram formados três grupos $(n=14)$ : C (controlo - coágulo de sangue), AB (osso autógeno) e AT (tecido adiposo fragmentado). Estes grupos foram divididos em subgrupos $(\mathrm{n}=7)$ para a eutanásia em 30 e 90 dias. Foram realizadas análises histológicas e imuno-histoquimico. Os dados foram submetidos à análise estatística descritiva (moda). Um fechamento ósseo completo foi observada no grupo $A B 90$ dias após a cirurgia. No grupo $C$ a reparação foi alcançada através da formação de feixes de fibras de colágeno orientadas paralelamente à superfície da ferida nos dois periodos pós-operatórios. No Grupo AT, o tipo de cicatrização predominante foi caracterizada pela presença de tecido conjuntivo denso contendo feixes de colágeno de fibras dispostas em meio ao tecido adiposo restante, com raras formações ósseas heterotópicas associada à fibrose e diferentes tipos de necrose tecidual. A imunomarcação do PPAR- $\gamma$ não foi observada em nenhum espécime dos grupos $C$ e $A B$. No grupo AT a imunomarcação do PPAR- $\gamma$ foi mais evidente aos 30 dias de pós-operátorio. A imunomarcação da osteocalcina estava presente em todos os grupos e nos dois periodos de pós-operatório 0 enxerto autógeno abdominal fragmentado tecido adiposo não favoreceu a reparação de defeitos ósseos de tamanho crítico criados cirurgicamente em calvária de ratos como evidenciado pela imunomarcação positiva da proteina PPAR- $\gamma$ e a imunomarcação negativa de osteocalcina nos osteoblastos e matriz óssea.

\section{References}

1. Misch $C E$, Dietsh F. Bone-grafting materials in implant dentistry. Implant Dent 1993;2:158-167.

2. Gomillion CT, Burg KJL. Stem cells and adipose tissue engineering, Biomaterials 2006:27:6052-6063.

3. Odorico JS, Kaufman DS, Thomson JA. Multilineage differentiation from human embryonic stem cell lines. Stem Cells 2001;19:193-204.

4. Cao $Y$, Sun $Z$, Liao L, Meng $Y$, Han $Q$, Zhao RC. Human adipose tissuederived stem cells differentiate into endothelial cells in vitro and improve postnatal neovascularization in vivo. Biochem Biophys Res Commun 2005;332:370-379.

5. Bunnell BA, Flaat M, Gagliardi C, Patel B, Ripoli C. Adipose-derived stem cells: isolation, expansion and differentiation. Methods 2008;45:115120.

6. Strem $\mathrm{BM}$, Hedrick $\mathrm{MH}$. The growing importance of fat in regenerative medicine. Trends Biotechnol 2005;23:64-66.

7. Cowan CM, Shi YY, Aalami 00, Chou YF, Mari C, Thomas R. Adiposederived adult stromal cells heal critical-size mouse calvarial defects. Nat Biotechnol 2004;22:560-567.

8. Zheng B, Cao B, Li G, Huard J. Mouse adipose-derived stem cells undergo multilineage differentiation in vitro but primarily osteogenic and chondrogenic differentiation in vivo. Tissue Eng 2006;12:18911901.

9. Cui L, Liu B, Liu G, Zhang W, Cen L, Sun J, et al.. Repair of cranial bone defects with adipose derived stem cells and coral scaffold in a canine model. Biomaterials 2007;28:5477-5486.

10. Wang S, Zhang J, Zhao X, Zhang X, Sun X, Xia L, et al.. Vertical alveolar ridge augmentation with beta-tricalcium phosphate and autologous osteoblast in canine mandible. Biomaterials 2009;30:2489-2498.

11. Zou J, Wang G, Geng D, Zhu X, Gan M, Yang H. A novel cell-based therapy in segmental bone defect: using adipose derived stromal cells. J Surg Res 2011;168:76-81.

12. Justesen J, Pedersen SB, Stenderup K, Kassem M. Subcutaneous adipocytes can differentiate into bone-forming cells in vitro and in vivo. Tissue Eng 2004;10:381-391.

13. Qu CQ, Zhang GH, Zhang LY, Yang GS. Osteogenic and adipogenic potential of porcine adipose mesenchymal stem cells. In vitro. Cell Dev Biol Anim 2007;43:95-100.

14. Matsubara FB, Zanicotti DG, Zielak JC, Giovanini AF, Gonzaga CC, de Andrade Urban $C$, et al.. Nonprocessed adipose tissue graft in the treatment of dehiscence bone defects in rabbit tibiae: a pilot study. Implant Dent 2012;21:236-241.

15. Gomes SP, Deliberador TM, Gonzaga CC, Klug LG, da Costa Oliveira L,

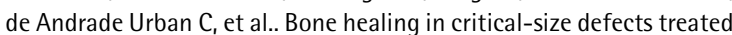
with immediate transplant of fragmented autogenous white adipose tissue. J Craniofac Surg 2012;23:1239-1244.

16. Chenu C, Colucci $S$, Grano M, Zigrino P, Barattolo R, Zambonin G, et al.. Osteocalcin induces chemotaxis, secretion of matrix proteins and calcium-mediated intracellular signaling in human osteoclast-like cells. J Cel Biol 1994;127:1149-1158.

17. Song L, Tuan RS. Transdifferentiation potential of human mesenchymal stem cells derived from bone marrow. FASEB J 2004;18:980-982.

18. Hoshiba T, Kawazoe N, Chen G. Mechanism of regulation of PPARG expression of mesenchymal stem cells by osteogenesis-mimicking extracellular matrices. Biosci Biotechnol Biochem 2011;75:2099-2104.

19. Kawai M, Sousa KM, MacDougald OA, Rosen CJ. The many facets of PPARgamma: novel insights for the skeleton. Am J Physiol Endocrinol Metab 2010:299:3-9.

20. Schmitz JP, Hollinger JO. The critical size defect as an experimental model for craniomandibulofacial nonunions. Clin Orthop 1986;205:299-308.

21. Frame JW. A convenient animal model for testing bone substitute materials. J Oral Surg 1980;38:176-180.

22. Dahlin C, Alberius $\mathrm{P}$, Linde A. Osteopromotion for cranioplasty: an experimental study in rats using a membrane technique. J Neurosurg $1991 ; 74: 487-491$. 